\title{
A COMMENTARY ON FRENCH LANGUAGE RIGHTS IN PROSECUTIONS OF PROVINCIAL OFFENCES IN ALBERTA*
}

\author{
WILLIAM HENKEL, Q.C.**
}

\begin{abstract}
This commentary is a technical analysis of the provisions of the North-West Territories Act, Alberta Act, Criminal Code, and Languages Act as such pertain to the right to use the French language in the courts of Alberta in respect of proceedings under the Summary Convictions Act. It is submitted that the passing of the Languages Act in 1988, rather than abridging French language rights, may partially restore to Albertans a right to use French in the courts which they have not had since 1946.
\end{abstract}

\section{TABLE OF CONTENTS}

\begin{abstract}
I. INTRODUCTION: THE REACTION IN ALBERTA TO R. v. MERCURE ....................... 302

II. THE RIGHT IN SASKATCHEWAN TO USE FRENCH IN CRIMINAL PROCEEDINGS . .............. 303

III. THE APPLICABILITY OF s. 110 OF THE NORTH-WEST TERRITORIES ACT TO CRIMINAL PROCEEDINGS IN ALBERTA . . ............. 305

IV. THE RIGHT TO USE FRENCH IN PROCEEDINGS UNDER THE SUMMARY CONVICTIONS ACT ...... 306

V. CONCLUSION: OUT, IN, OUT ............... 308
\end{abstract}

\section{INTRODUCTION: THE REACTION IN ALBERTA TO $R$. v. MERCURE}

In $R$. v. Mercure' an accused charged with a speeding offence made a preliminary application to be permitted to enter a plea in French, to have his trial proceeded with in French and to have the hearing delayed until the clerk of the Saskatchewan Legislative Assembly could deliver the relevant provincial legislation in French. This preliminary application gave rise to the following question: ${ }^{2}$

Does any right to a trial in the French language arise under the laws of the Province of Saskatchewan by reason of the possible incorporation of $\mathrm{s} .110$ of the North-West

Territories Act into the laws of Saskatchewan by s. 16(1) of the Saskatchewan Act?

"The author would like to thank Professor Gerald Gall for reading the "commentary" and encouragement to publish, and Patrick Bendin, Counsel, Department of Justice, for his editorial assistance, including many aspects of the wording of the commentary, and useful suggestions, too numerous to mention.

The substantive part of the article including any legal shortcomings and flaws in reasoning must be attributed to the author.

** General Counsel, Edmonton, Alberta.

1. [1988] 2 W.W.R. 577 (S.C.C.).

2. Id. at 584 . 
Section 110 of the North-West Territories Act ${ }^{3}$ reads:
Either the English or the French language may be used by any person in the debates of the Legislative Assembly of the Territories and in the proceedings before the courts; and both those languages shall be used in the records and journals of such Assembly; and all ordinances made under this Act shall be printed in both those languages: Provided, however, that after the next general election of the Legislative Assembly, such Assembly may, by ordinance or otherwise, regulate its proceedings, and the manner of recording and publishing the same; and the regulations so made shall be embodied in a proclamation which shall be forthwith made and published by the Lieutenant Governor in conformity with the law, and thereafter shall have full force and effect.

In answering the question in the affirmative the Supreme Court of Canada in the Mercure case held as follows: ${ }^{4}$

(1) S. 110 continued to apply to the Province of Saskatchewan by virtue of ss. 14 and 16 of the Saskatchewan Act.

(2) S. 110 is not an entrenched provision.

(3) While the Legislature of Saskatchewan could unilaterally modify or repeal s. 110 such changes would have to be done in the manner and form required by law; in this case, by legislation in English and French.

(4) At the time the accused was charged with a speeding offence, s. 110 had yet to be repealed or otherwise modified.

Since the provisions of the Alberta Act ${ }^{s}$ dealing with the incorporation of laws of the Northwest Territories are identical to those in the Saskatchewan Act, ${ }^{6}$ the decision in the Mercure case raised the question of whether its conclusions were also applicable to Alberta. The answer of the Legislature of Alberta came with the enactment of the Languages Act ${ }^{7}$ and the replacement of s. 110 of the North-West Territories Act with a provision which permits French to be used in Alberta courts only in oral communication. In other words, in so far as the right to use French in the courts is concerned, it would appear from the Languages Act that the Legislature took the view that the situation in Alberta was no different from that in Saskatchewan.

The purpose of this commentary is to demonstrate that the legislative circumstances of the two provinces may be distinguishable and that, rather than derogating from a pre-existing right, the Languages Act may partially restore to Albertans a right to use French in the courts which they have not had since 1946.

\section{THE RIGHT IN SASKATCHEWAN TO USE FRENCH IN CRIMINAL PROCEEDINGS}

In Reference Re French in Criminal Proceedings ${ }^{8}$ the Lieutenant Governor-in-Council of the Province of Saskatchewan referred five questions to the Saskatchewan Court of Appeal pertaining to the use of

3. R.S.C. 1886 , c. 50 (am. 1891 , c. 22 , s. 18 ).

4. Supra n. 1 at 643-644.

5. 4-5 Edw. VII, c. 3 (Can.), R.S.C. 1906, c. 3, reproduced infra in the text.

6. 4-5 Edw. VII, c. 42 (Can.), R.S.C. 1906, c. 42.

7. S.A. 1988 , c. L-7.5, ss. 4 and 7.

8. (1988) 44 D.L.R. (4th) 16 (Sask. C.A.). 


\section{French in the province's superior courts of criminal jurisdiction. Two of the questions read as follows: ${ }^{9}$}

(1) Did subsection 16(2) of the Saskatchewan Act carry forward, or continue into effect, section 110 of the North-West Territories Act, R.S.C. 1886, c. 50, as the same existed prior to September 1, 1905 as part of the procedure in criminal matters then obtaining in respect of the Supreme Court of the Northwest Territories?

(2) If the answer to question 1 is in the affirmative, does section 110 continue to apply to criminal proceedings in the superior courts of criminal jurisdiction in Saskatchewan?

\section{Upon answering the first question in the affirmative the court dealt as follows with the second question: ${ }^{10}$}

Subject to the power of the federal executive, by declaration, to render inapplicable the former procedure - which it did not do - s. 16(2) of the Saskatchewan Act contemplated the continued application, in the new superior court of criminal jurisdiction, of procedure in criminal matters, only "until otherwise provided by competent authority". Counsel for the Attorney-General of Saskatchewan contended that, while no provincial action could be pointed to, the same could not be said for Parliament.

The enactment by Parliament of s. 9 of the Criminal Code, R.S.C. 1927, c. 36, was said to have brought to an end the right of accused persons to use French in criminal proceedings before the superior courts of the province. That section provided that the Code "shall extend to and be in force throughout Canada" with certain exceptions, none of which included any reference, as had s. 9 of the earlier code (R.S.C. 1906, c. 146), to Saskatchewan and the North-West Territories Act. The earlier provisions read thus:

9. Except in so far as they are inconsistent with the North-West Territories Act and amendments thereto as the same existed immediately before the first day of September, one thousand nine hundred and five (the day Saskatchewan and Alberta came into being), the provisions of this Act extend to and are in force in the provinces of Saskatchewan and Alberta ...

As a consequence of this earlier provision it was said that the procedure in criminal matters was then an amalgam of that provided for in the North-West Territories Act, and the Criminal Code then in effect (R. v. Standard Soap Co. (1907), 12 C.C.C. 290 at pp. 296-7 (N.W.T.S.C. en banc)), which procedure included, among other things, the s. 110 right to use French, but that on the re-enactment of s. 9 in 1927, all of that changed, the procedural provisions of the North-West Territories Act, so far as they extended to Saskatchewan, including the right to use French, were displaced.

That may very well be so in relation to those wholly procedural provisions of the NorthWest Territories Act which were inconsistent with the procedural provisions of the Criminal Code, a matter we need not get into, but it is not so, in our opinion, with respect to the s. 110 right to use French before the province's superior courts.

Given that language provisons have been held by the Supreme Court of Canada to be in the nature of procedure ${ }^{11}$ it is unclear why, when the reference to Saskatchewan was dropped from s. 9 of the Criminal Code, the wholly procedural provisions of that enactment would not also have taken precedence over s. 110 of the North-West Territories Act. In any event, it is submitted that the same conclusion does not hold in Alberta.

9. Id. at 22 and 24 .

10. Id. at 24 and 25 .

11. R. v. Paquette [1988] 1 W.W.R. 97 at 103 (Alta. C.A.) citing Jones v. A.G.N.B. [1975] 2 S.C.R. 182 (sub nom. Jones v. A.G. Can.). 


\section{THE APPLICABILITY OF S. 110 OF THE NORTH-WEST TERRITORIES ACT TO CRIMINAL PROCEEDINGS IN ALBERTA}

\section{Section 16(2) of the Alberta Act ${ }^{12}$ reads:}

The Legislature of the province may for all purposes affecting or extending to the said province, abolish the Supreme Court of the Northwest Territories, and the offices, both judicial and ministerial, thereof, and the jurisdiction, powers and the authority belonging or incident to the said court: Provided that, if, upon such abolition, the Legislature constitutes a superior court of criminal jurisdiction, the procedure in criminal matters then obtaining in respect of the Supreme Court of the Northwest Territories shall, unless otherwise provided by competent authority, continue to apply to such superior court and that the Governor in Council may at any time and from time to time declare all or part of such procedure to be inapplicable to such superior court.

When the Province of Alberta set up its superior courts on February 11, $1907^{13}$ the criminal procedure then obtaining in the Northwest Territories did not include s. 110 of the North-West Territories Act which had been repealed by the Revised Statutes of Canada Act ${ }^{14}$ on January 30, 1907. However, prior to the repeal of the North-West Territories Act, the Criminal Code was amended to include the following provision: ${ }^{15}$

9. Except in so far as they are inconsistent with the North-West Territories Act and amendments thereto as the same existed immediately before the first day of September, one thousand nine hundred and five, the provisions of this Act extend to and are in force in the provinces of Saskatchewan and Alberta, the Northwest Territories, and, except in so far as inconsistent with the Yukon Act, the Yukon Territory. 55-56 V., c. 29, s. 983.

Thus, if s. 110 of the North-West Territories Act applied to superior courts of Alberta in February of 1907, it did so only as a result of s. 9 of the Criminal Code.

\section{In $1927 \mathrm{s.} 9$ of Criminal Code was amended to read: ${ }^{16}$}

9. The provisions of this Act shall extend to and be in force throughout Canada, except: (c) in the Province of Alberta in so far as they are inconsistent with the North-West Territories Act and amendments thereto as the same existed immediately before the first day of September one thousand nine hundred and five, but with such changes as have been subsequently made by competent authority. R.S. (1886), c. 50; 1905, c. 3; R.S. (1906), c. 146, s. 9 .

the Parliament of Canada being the "competent authority" introducing this amendment.

However, in 1946, s. 9(c) was repealed and the provisions of the NorthWest Territories Act which were specifically to apply to Alberta were

12. Supran. 5.

13. The Supreme Court Act, S.A. 1907, c. 3.

14. 6-7 Edward VII, c. 43 (Can.).

15. R.S.C. 1906 , c. 146.

16. R.S.C. 1927 , c. 36 . 
inserted elsewhere in the Criminal Code. ${ }^{17}$ In that regard ss. 2 and 3 of the amending legislation provided:

2. The said Act is further amended by adding immediately after section five hundred and eighty-one the following section:

581A. Notwithstanding any other provision of this Act, any person charged with an indictable offence in the Province of Alberta may, with his own consent, be tried by a judge of the superior court of criminal jurisdiction of Alberta without the intervention of a jury.

3. Subsection six of section nine hundred and twenty-seven of the said Act, as enacted by section twenty-eight of chapter twenty-three of the statutes of 1943-44, is repealed and the following substituted therefor:

"(6) Notwithstanding the provisions of subsections four and five of this section, in the Province of Alberta six jurors only shall be sworn."

It is submitted that the decision of Parliament not to include any reference to s. 110 of the North-West Territories Act resulted in its repeal from the Criminal Code.

\section{THE RIGHT TO USE FRENCH IN PROCEEDINGS UNDER THE SUMMARY CONVICTIONS ACT}

An examination of how the removal of the reference to s. 110 of the North-West Territories Act from the Criminal Code affects procedure under the Summary Convictions $\mathrm{Act}^{18}$ raises an antecedent question, namely: Did s. 110 apply to courts of inferior jurisdiction?

Since the only references in s. 16(2) of the Alberta Act are to the Supreme Court of the Northwest Territories and a superior court of criminal jurisdiction constituted by the Legislature of Alberta, it is arguable that $s$. 110 of the North-West Territories Act only applied to these courts. As Stevenson, J.A. of the Alberta Court of Appeal noted in R. v. Paquette:19

There is an anomaly in this legislation in that there is no specific provision dealing with "courts" other than the Supreme Court. The other "courts" were not then courts of record and there was no need to talk in terms of abolition of them. The new province of Alberta simply assumed responsibility for the appointment of "police magistrates" and justices of the peace (S.A. 1906, c. 13).

He then went on to make the following observation in respect of prosecutions under the Criminal Code: ${ }^{20}$

Section 110 of the North-West Territories Act is legislation in relation to courts; it is also legiuslation in relation to criminal procedure. Criminal procedure was not, indeed could not, be affected by the province. I am of the view that the saving provision of $\mathrm{s}$. $16(2)$, by necessary implication, must be applied to those "courts" which were subject to federal authority over criminal procedure. In view of the conclusion I reach in this judgment it is, strictly speaking, unnecessary to make this determination because there is no suggestion that the accused's rights under s. 110, properly interpreted, will be ignored by the court hearing the preliminary inquiry.

With the decision of the Supreme Court of Canada in Mercure, however, it appears to have been settled that in so far prosecutions under the Summary Convictions Act are concerned, s. 16(2) of the Alberta Act

17. S.C. 1946, c. 20.

18. R.S.A. 1980, c. S-26.

19. [1988] 1 W.W.R. 97 at 103.

20. Id. at 104. 
operated to continue s. 110 of the North-West Territories Act in respect of courts of inferior jurisdiction. In that regard LaForest, J. stated:21

\begin{abstract}
As Bayda C.J.S., speaking for the majority of the (Saskatchewan) Court of Appeal, observed, the law "pertaining to languages, is not tied to a specific institution" in that part of s. 110 dealing with the courts. I agree with him . . . therefore, that "This means that different courts can come and go but the law remains and applies irrespective of those comings and goings". Belzil J.A. in R. v. Lefebvre, supra, at pp. 140-41, observed that this is, in fact, what happened before the enactment of the Saskatchewan Act. When s. 110 was first passed, he stated, the courts which the provision affected were those of the stipendiary magistrates, but when these were replaced by the Supreme Court of the North West Territories the provision continued to apply to it. In like manner, s. 110 continued to apply when the latter court was replaced by the Supreme Court and other courts of the province. It should be remembered that when the Supreme Court of the Territories was continued in the province, it did so no longer as a territorial court but as a Saskatchewan court. It was disestablished in what remained of the Territories by the North-West Territories Amendment Act, 1905, S.C. 1905, c. 27, ss. 2 and 8, enacted on the same day as the Saskatchewan Act. The subsequent restructuring of the courts in no way changed the law applicable generally to all courts.
\end{abstract}

As a general principle, if a provincial legislature has the jurisdiction to enact laws in respect of a particular subject-matter, it also has the power to pass legislation which incorporates similar laws enacted by another legislative body. Hence, even though the Legislature of Alberta could have enacted its own procedural provisions under the Summary Convictions Act, it chose, instead, to incorporate much of the procedure set forth in Part XXVII of the Criminal Code, ${ }^{22}$ including the amendments to that Part. In that regard, s. 5 of the Summary Convictions Act in force in 1946, read as follows: ${ }^{23}$

5. Except as otherwise provided, the provisions of the Criminal Code of Canada respecting summary convictions, as amended from time to time, and the proceedings relating thereto, shall apply in respect of all convictions and all orders and the proceedings relating thereto, made or to be made by any justice.

The incorporating provision was subsequently amended and now reads: ${ }^{24}$

4(1) Except as otherwise specially provided, the provisions of the Criminal Code of Canada respecting summary convictions, as amended from time to time, and the proceedings relating thereto, shall apply in respect of all convictions and all orders and the proceedings relating thereto, made or to be made by any justice.

(2) Without restricting the generality of subsection (1), sections 448 to $454,457.6$ and 457.8 to 459 of the Criminal Code (Canada) apply, with all necessary modifications, to all matters to which this Part applies.

(3) Section 662.1 of the Criminal Code (Canada) does not apply to any matter to which this Part applies.

Thus, when reference to s. 110 of the North-West Territories Act was repealed from the Criminal Code, it was also repealed from the Summary Convictions Act. Furthermore, such repeal, having been effected through a statute "enacted, printed and published in the English and French languages"2s also met the requirement enunciated by LaForest, J. in the

21. R. v. Mercure, supra n. 1 at 630.

22. R.S.C., 1985, c. C-42.

23. R.S.A., 1942, c. 147.

24. Summary Convictions Act, supra n. 16.

25. R. v. Mercure, supra n. 1 at 642. 
Mercure case that "it be done in the manner and form required by law for the time being in force". ${ }^{26}$

\section{CONCLUSION: OUT, IN, OUT}

The history of s. 110 of the North-West Territories Act in relation to prosecutions of criminal and provincial offences in Alberta has been marked by the rhythm of a legal three-step. That is:

(1) Out

When The Supreme Court Act ${ }^{27}$, which set up the superior courts of Alberta was assented to on February 11, 1907, the criminal procedure then obtaining in the Northwest Territories did not include s. 110.

(2) In

However, s. 110 was made part of the criminal procedure applicable to Alberta through an amendment to the Criminal Code which came into effect in 1907.

(3) Out

S. 110 remained part of the Criminal Code and therefore, the Summary Convictions Act, until its repeal in 1946.

Hence, rather than abridging French language rights the Languages Act has served to codify the right of Albertans to use French in oral communications before the courts of the province in respect of proceedings under the Summary Convictions Act.

26. Id.

27. Supra, n. 13. 